IJMS 17 (Special Issue), 63-84 (2010)

\title{
PREDICTIVE POWER OF OUTPUT GROWTH, INFLATION, AND INTEREST RATE ON STOCK RETURN AND VOLATILITY: A COMPARISON
}

\author{
WAI CHING POON \\ School of Business \\ Monash University \\ GEE KOK TONG \\ Faculty of Information Technology \\ Multimedia University
}

\begin{abstract}
Using monthly data from seven mature and emerging markets and a battery of GARCH and EGARCH models, the study of Davis and Kutan (2003) on inflation and output on stock returns and volatility is extended by including interest rate to compare the effect between three mature markets (US, Japan, and Singapore) and four emerging markets who experienced a crisis before (Malaysia, India, Korea, and Philippines). It is found that economic volatility, as measured by movement in inflation, output growth, and interest rate, have a weak predictor power for stock market volatility and returns. In line with the evidence reported in Davis and Kutan (2003), the findings suggest that there is no support for the Fisher effect in stock returns among the seven mature and emerging markets.
\end{abstract}

Keywords: Predictive power; output; inflation; interest rate; stock return volatility.

\section{Introduction}

In conjunction with the financial crisis and the substantial variability in production levels, a question on the relationship between stock returns and economic activity arises (Mauro, 2000). Study on the impact of inflation, output growth, and interest rate movement on conditional stock market volatility has important implications for investors and policy makers. High market volatility would increase market risk premium which is unfavourable for investment. It is important for policy makers to reduce stock market volatility and 
ultimately enhance the stability of the economy in order to improve the effectiveness of asset allocation decisions.

While previous studies have examined the relationship between macroeconomic factors and stock return volatility, there is no study on real output, inflation and interest rate together as exogenous variables in both the mean and conditional variance equations to simultaneously estimate the effect of these variables on stock market returns.

This paper is the extension of Davis and Kutan's (2003) study which employed Generalised Auto-Regressive Conditional Heteroscedasticity (GARCH) and exponential GARCH (EGARCH) models to simultaneously estimate the predictive power of real output and inflation on monthly stock returns and volatility using data from 13 countries. The main purpose of this paper is to estimate the predictive power of output growth, inflation, and interest rate on monthly stock return and their conditional volatility using data from three mature markets (hereafter $\mathrm{MM}$ ) and four Asia emerging markets (hereafter EM) to predict nominal stock returns. This paper employed GARCH and EGARCH models, as proposed by Bollerslev (1986) and Nelson (1991) respectively, since these models account for conditional volatility. Furthermore, the EGARCH model is suitable for asymmetric volatility time series data, considering time varying volatility (volatility clustering) on stock return. The result can also be used to explain the volatility of stock market return and prove the validity of Fisher effect in international stock returns.

This paper is organised as follows: Section 2 provides a review of the relevant literature. Section 3 outlines the methodology, and presents data used and sample period. Section 4 discusses the empirical results and the implications of the findings, and section 5 concludes the paper.

\section{Literature Review}

Studies on stock market volatility have been reported in the extant literature. The variability of the market factor of the New York Stock Exchange is linked to the volatility of macroeconomic variables (Officer, 1973). Past studies showed mixed evidence in relation to the link between stock returns and output economic activity. McQueen and Roley (1993) claimed a positive relation between future economic activity and stock returns. The positive linkage between the two can be through a channel mechanism where higher stock returns have a 
bi-directional effect on higher consumption and investment levels that ultimately enhances economic activity. On the other hand, empirical evidence had indicated a negative linkage between stock returns and past economic activity for the USA (Balvers, Cosimano \& McDonald, 1990). Also, Tsouma (2008) explained the existence of a negative linkage between current economic activity and future stock returns. However, it does not always show a negative significant relationship in the G-7 countries (Hassapis \& Kalyvitis, 2002). Similarly, Lee (1992) found that economic activity does not significantly explain the variability in stock returns in the US economy. Also, Binswanger (2000) found that no predictor variations in future returns correlated with economic activity for the US economy during the period 19841997.

Campbell and Hentschel (1992), Braun, Nelson, and Sunier, (1995), and Bekaert and Harvey (1997) found that there were time-varying volatilities in stock return. Aggarwal, Indan, and Leal (1999), who studied volatility in emerging stock markets, found that during the Mexican peso crisis, the Filipino Marcos-Aquino conflict, and the Indian stock market scandal, significant volatility in the stock market took place, with higher volatility during recession (Schwert, 1989a). Therefore, it is hypothesised that higher predictive power of output growth and inflation on monthly stock return and volatility in the financial crisis country, a priori.

Schwert (1989a) studied the relation of stock volatility with economic activity, financial leverage, and stock trading activity using the US monthly data from 1857 to 1987 . Results revealed that aggregate leverage is significantly correlated with volatility and explained relatively small movements in stock volatility. Using simple models of stock valuation, he characterised the changes in stock market volatility to time-varying volatility was unusually high during the Great Depression, and found weak evidence of inflation, industrial production growth rates, and monetary base growth rates in predicting stock market volatility. Schwert believed that the conditional variance of stock prices is proportional to the conditional variance of the expected future cash flows if discount rates are constant over time. In addition to that, Schwert (1989b) showed that stock volatility increases for immediate effect following the worst panics, but there is absence of long-term effects on volatility.

Stock return volatility is correlated with interest rate (Schwert, 1989a). Mascaro and Meltzer (1983) found that macroeconomic volatility is related to long-and short-term interest rate. Many studies investigated 
the interdependency between stock returns and interest rate, yet the evidence is mixed. Previous studies found negative correlation between changes in interest rate and stock returns, such as Fama and Schwert (1977), and Geske and Roll (1983). Peiro (1996) further argued that stock returns are affected by current changes in the interest rate and by future changes in production. The changes in interest rate seem to be higher than changes in production. Domian, Gilster, and Louton (1996) argued that falls in interest rate are followed by 12 months of excess stock returns while increases in interest rates have little effect. However, Titman and Warga (1989) found a positive relation between stock return and future interest rate changes.

Fisher (1930) asserted that the nominal interest rate consists of a real rate plus the expected inflation rate. Fisher Hypothesis stated that the expected real rate of economy is determined by the real factors such as productivity of capital and time preference of savers, and it is independent of the expected inflation rate. If this Fisher effect 4 holds, there is no change in inflation and nominal stock returns, since stock returns are allowed to act as a hedge for inflation. Some had opposed the Fisher Hypothesis, and claimed that the real rates of common stock return and expected inflation rates are independent and that nominal stock returns vary in one-to-one correspondence with expected inflation. On the other hand, using Pigou real wealth effect, Mundell (1963) revealed that the real rate of interest is negatively related to expected inflation. Santomero (1973) showed that changes in the growth rate of the labour productivity may give rise to a direct relation between the expected real rate and expected inflation. Furthermore, introducing progressive income taxes may cause further dependencies between the two variables.

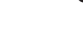

\section{Methodology}

\section{Country Selection}

Seven countries were selected in this study, where three were MM (Japan, USA, Singapore) and four were Asia EM that experienced financial crisis before (Malaysia, Korea, Philippines, and India). The country selection criteria were driven by data availability.

\section{Data}

Monthly data on stock price indices, industrial production index, and Consumer Price Index (CPI), treasury bills rate, and money market 
rate for the sample period were used in this research. Our data sample for most countries are available from different starting periods and the same ending period as shown in Table 2. The data for Japan and US are available from 1957 August, while most of the data for EM started from early 1980s. All data were obtained from International Financial Statistics (IFS) database. Due to data unavailability, the manufacturing production index was used as a proxy for industrial production index for the Philippines. T-Bills Rate was used as proxy for changes in short-term interest rate for US, Malaysia, and Singapore, while money market rates were used for Japan, Korea, Philippines, and India, while taking the logarithmic difference of the stock indices, CPI and industrial production indices to generate stock return, inflation, and output growth, respectively. All variables were log-differenced based, multiplied by 100 . Most time series data became stationary after the first difference but this transformation often exhibited volatility, suggesting variance of financial time series varies over time. In order to overcome this problem, GARCH and EGARCH were used to account for "varying variance".

Table 1

Events Influencing Volatility in Selected Emerging Markets

\begin{tabular}{lll}
\hline Countries & Period & Events \\
\hline India & 24-9-1975 & $\begin{array}{l}\text { Rupee's ties to Pound sterling were } \\
\text { broken, and floating to a basket of } \\
\text { currencies. } \\
\text { Balance of payments crisis, unstable } \\
\text { government due to elections. } \\
\text { IMF and World Bank approved } \\
\text { emergency loans to repay international } \\
\text { debts. }\end{array}$ \\
& July 1991 & $\begin{array}{l}\text { Stock market scandal. } \\
\text { Controls on capital and money market } \\
\text { instruments. }\end{array}$ \\
15-4-1992 to 27-5-1997 & $\begin{array}{l}\text { Banking crises due to economic } \\
\text { recession, bubble burst and weak } \\
\text { demand. }\end{array}$ \\
& 21-10-1987 to 20-1-1988 & $\begin{array}{l}\text { October 1987 crash, Chinese-Malay } \\
\text { riots. } \\
\text { Increased reserved requirements, } \\
\text { capital control measures. } \\
\text { Capital control. } \\
\text { Pegged exchange rate to USD. }\end{array}$ \\
\hline
\end{tabular}

(continued)

IJMS 17 (Special Issue), 63-84(2010) 


\begin{tabular}{|c|c|c|}
\hline Countries & Period & Events \\
\hline \multirow{5}{*}{ Philippines } & $21-8-1983$ & Beginning of capital flight. \\
\hline & $26-2-1986$ to $16-9-1987$ & Marcos-Aquino conflict, coup attempt. \\
\hline & $5-4-1989$ to $27-3-1991$ & Debt problems, coup attempt. \\
\hline & February 1992 & $\begin{array}{l}\text { The IMF approved an extension of } \\
18 \text {-month standby credit. }\end{array}$ \\
\hline & August 1992 & $\begin{array}{l}\text { The government lifted all foreign } \\
\text { exchange restrictions allowing foreign } \\
\text { investors to freely repatriate their } \\
\text { capital. }\end{array}$ \\
\hline \multirow[t]{5}{*}{$\begin{array}{l}\text { South } \\
\text { Korea }\end{array}$} & 1984 & Minimum and maximum bank interest \\
\hline & $18-4-1990$ to $16-1-1991$ & Large trade deficit. \\
\hline & January 1992 & Stock market was opened to investors. \\
\hline & November 1997 & $\begin{array}{l}\text { The government abandoned its defense } \\
\text { of won, sought loan from IMF. }\end{array}$ \\
\hline & December 1997 & Korea got bailout package from IMF. \\
\hline
\end{tabular}

Note. Adapted from Aggarwal et al. (1999), Bakaert and Harvey (2004).

\section{Method}

GARCH as proposed by Bollerslev (1986) is employed to check whether the monthly stock returns used have time-varying volatility, while EGARCH model as proposed by Nelson (1991) is employed to check whether shock to the monthly stock returns volatility are asymmetric. Then, estimate the impact of output growth, inflation, and interest rate on stock markets returns and their volatility. Following Bollerslev and Wooldridge (1992), robust variance estimator is employed to compute asymptotic standard errors. A comparison study of volatility between MM and EM are carried out. Table 1 shows the information of the four selected EM in relation to the important events that cause sudden changes in volatility.

Following Davis and Kutan (2003), the conditional variance was modelled by a GARCH $(1,1)$ specification. Monthly seasonal dummies variables were used in the GARCH and EGARCH models. In the standard GARCH $(1,1)$ specification introduced by Bollerslev (1986), the mean equation in Eq.(1) is written as a function of exogenous or predetermined endogenous variables $x_{t}{ }^{\prime}$ with an error term. The estimated conditional variance, $\sigma_{t}^{2}$ is the one-period ahead forecast variance based on its past information. The conditional variance equation specified in Eq.(2) is a function of constant variance $(\omega)$, news about the volatility from the previous period, which is measured 
as the lag of the squared residual from the mean equation, $\varepsilon_{t-1}^{2}$ (the $\mathrm{ARCH}$ term) and the past variance, $\sigma_{t-1}^{2}$ (the GARCH term).

$y_{t}=x_{t}^{\prime} \gamma+\varepsilon_{t}$

$\sigma_{t}^{2}=\omega+\alpha \varepsilon_{t-1}^{2}+\beta \sigma_{t-1}^{2}$

GARCH model is estimated by the method of maximum likelihood under the assumption that the error terms are conditionally normally distributed. GARCH $(1,1)$ refers to the presence of a first-order GARCH term and a first-order ARCH term. For GARCH $(1,1)$ model, the contribution to the log likelihood from observation $t$ is as follows:

$l_{t}=-\frac{1}{2} \log (2 \pi)-\frac{1}{2} \log \sigma_{t}^{2}-\frac{1}{2}\left(y_{t}-x_{t}^{\prime} \gamma\right)^{2} / \sigma_{t}^{2}$

where

$\sigma_{t}^{2}=\omega+\alpha\left(y_{t-1}-x_{t-1}^{\prime} \gamma\right)^{2}+\beta \sigma_{t-1}^{2}$

This model is consistent with the volatility clustering, where large changes in returns are likely to be followed by further large changes (Eviews User's Guide).

For countries that experience asymmetric stock return volatility because of the downward movements in the market are followed by higher volatilities than upward movements in the same magnitude. This phenomenon happens because good and bad news generate different impact on stock return volatility. EGARCH $(1,1)$ or exponential GARCH model as proposed by Nelson (1991) is employed to account for this phenomenon. The specification for the conditional variance used is shown in Eq. (5).

$\log \sigma_{t}^{2}=\omega+\beta \log \sigma_{t-1}^{2}+\alpha\left|\frac{\varepsilon_{t-1}}{\sigma_{t-1}}\right|+\gamma \frac{\varepsilon_{t-1}}{\sigma_{t-1}}$

The left hand side of Eq.(5) is the log of the conditional variance. This implies that the leverage effect is exponential, and this will guarantee that the forecast of the conditional variance will not be negative. The presence of the leverage effects can be tested by the hypothesis that $\gamma>0$. The impact is asymmetric if $\gamma \neq 0$. 
It is noteworthy that two differences between the Eviews specification of the EGARCH model and the original model proposed by Nelson (1991). Firstly, Nelson assumes that $\varepsilon$ follows a generalised error distribution, Eviews assumes normally distributed errors. Secondly, Nelson's specification for the log conditional variances differs slightly from the specification above. Nelson (1991) specification for the log conditional variance is stated in Eq.(6).

$$
\log \sigma_{t}^{2}=\omega+\beta \log \sigma_{t-1}^{2}+\alpha\left(\left|\frac{\varepsilon_{t-1}}{\sigma_{t-1}}\right|-\sqrt{\frac{2}{\pi}}\right)+\gamma \frac{\varepsilon_{t-1}}{\sigma_{t-1}}
$$

Estimating this model under the assumption of normal errors yields identical estimates to those reported by Eviews except for the intercept term $\omega$, which differs by $\alpha\left(\sqrt{\frac{2}{\pi}}\right)$ (Eviews User's Guide).

(1) The predictive power of output growth and inflation on stock returns and volatility was examined by using GARCH $(1,1)$ or EGARCH $(1,1)$ after the suitable models for stock returns have been determined. Hamilton and Lin (1996) used Eq.(7) and Eq.(8) to model the conditional variance of stock returns as a function of past squared forecast economic variables that may affect the conditional variance.

$$
\begin{aligned}
& y_{t}=I_{t} \gamma+\varepsilon_{t} \\
& \sigma_{t}^{2}=\omega+\alpha \varepsilon_{t-1}^{2}+\beta \sigma_{t-1}^{2}+\sum_{i=1}^{k} u_{i}(\text { OutputGrowth })_{t-i}+\sum_{i=1}^{k} \lambda_{i}(\text { Inflation })_{t-i}
\end{aligned}
$$

This paper modified the model used by Hamilton and Lin (1996), and incorporated the model with three lags as suggested by Davis and Kutan (2003) because the stock market reacts to information relatively faster than goods market. Also, we employed Bollerslev and Wooldridge's (1992) robust variance estimator to compute asymptotic standard errors since the residuals may not be conditionally normally distributed. When the assumption of conditional normality does not hold, the ARCH parameter will still be consistent, provided the mean and variance functions are correctly specified. The estimates of the covariance matrix will not be consistent unless this option is specified. The parameter estimates are unchanged using this option but the estimated covariance matrix will be altered. Hence, the models that were employed are shown in Eq.(9) and Eq.(10). Some differences exist between the present specification and that of Hamilton and Lin (1996). This paper takes a long-run view and examines the impact 
of overall output volatility on stock market volatility, but Hamilton and Lin focused on the impact of regime changes of recessions on stock market volatility. Also, this paper includes output growth in both mean and variance equation. Inflation variable is included in both mean and variance equation to test the validity of the Adaptive Expected Fisher Effect to make some inferences about the central behaviour.

$R_{t}=I_{t} \gamma+\sum_{i=1}^{k} a_{i}(\text { OutputGrowth })_{t-i}+\sum_{i=1}^{k} b_{i}(\text { Inflation })_{t-i}+\varepsilon_{t}$

$\sigma_{t}^{2}=\omega+\alpha \varepsilon_{t-1}^{2}+\beta \sigma_{t-1}^{2}+\sum_{i=1}^{k} u_{i}(\text { OutputGrowth })_{t-i}+$

$\sum_{i=1}^{k} \lambda_{i}(\text { Inflation })_{t-i}$

Next, the Inflation-Output-Interest Rate-Stock Return (IOIS) model as shown in Eq.(11) and Eq.(12) is employed to analyse the effect of inflation, output growth, and interest rate changes on stock return and volatility simultaneously.

$R_{t}=I_{t} \gamma+\sum_{i=1}^{k} a_{i}(\text { OutputGrowth })_{t-i}+\sum_{i=1}^{k} b_{i}(\text { Inflation })_{t-i}+$

$\sum_{i=1}^{k} c_{i}(\text { Interest })_{t-i}+\varepsilon_{t}$

$\sigma_{t}^{2}=\omega+\alpha \varepsilon_{t-1}^{2}+\beta \sigma_{t-1}^{2}+\sum_{i=1}^{k} u_{i}(\text { OutputGrowth })_{t-i}+$

$\sum_{i=1}^{k} \lambda_{i}(\text { Inflation })_{t-i}+\sum_{i=1}^{k} \psi_{i}(\text { Interest })_{t-i}$

The specification in Eq.(5) in EGARCH $(1,1)$ model was used whenever the asymmetric volatility evidence exists to replace the specification in Eq.(10) and Eq.(12).

\section{Empirical Results}

\section{Descriptive Statistics}

Table 2 reports the descriptive statistics for stock return, inflation, output growth and interest rate for all seven countries. Results 
revealed that the mean monthly stock returns ranged from $0.40 \%$ to $1.51 \%$. For inflation, it ranged from $0.09 \%$ (Singapore) to $0.73 \%$ (Philippines). Results indicated that the monthly stock returns volatility and inflation are higher for EM than MM on the average (except for Singapore). The output growths in Asia EM are higher as compared to US and Japan. Philippines has the highest stock returns with the highest standard deviation (17.66\%), which shows that high return is accompanied by high risk. Also, high inflation country like Philippines tend to have higher stock returns, while low inflation country like Singapore is associated with relatively lower returns. In term of output growth, Philippines $(0.87 \%)$ experienced the highest output growth rate whereas US $(0.25 \%)$ experienced the lowest output growth rate. The rest of the countries tend to share about the same level of variation in their stock returns. Output growth is the most volatile in Singapore, while it is lowest in the US. The rest of the countries do not appear to differ much with respect to output deviations. Japan has the highest average interest rate growth during the sample period, with a negative monthly growth rate of $0.53 \%$, while Malaysia is experiencing the lowest interest rate growth of $0.007 \%$. US, Malaysia and Korea are having relatively lower deviation, and Japan, Philippines and India are having large deviation with respect to interest rate.

\section{Time Varying Volatility}

The result of the estimated coefficients for the standard GARCH $(1,1)$ model is reported in Table 3. All countries show significant timevarying volatility in stock returns. It shows that the specification of standard GARCH $(1,1)$ fit the countries under study. To check whether stock returns for the country is associated with asymmetric volatility, we diagnosed using EGARCH $(1,1)$. The result of EGARCH $(1,1)$ estimation is reported in Table 4 . Results showed that six out of seven countries are better fitted with EGARCH $(1,1)$ model than the standard GARCH model. This implies that these countries do show asymmetric volatility in their stock returns and better represent the majority of stock returns in this sample. For the rest of the empirical analysis, six countries (Japan, USA, Malaysia, Singapore, Philippines, and India) were examined using EGARCH $(1,1)$, while GARCH $(1,1)$ model was applied for Korea. From Tables 3 and 4, there is significant evidence to show time-varying volatility in stock returns for both MM and EM. This result is consistent with the claimed made by Bekaert and Harvey (1997), Aggarwal et al. (1999), and Davis and Kutan (2003) for emerging market returns. 


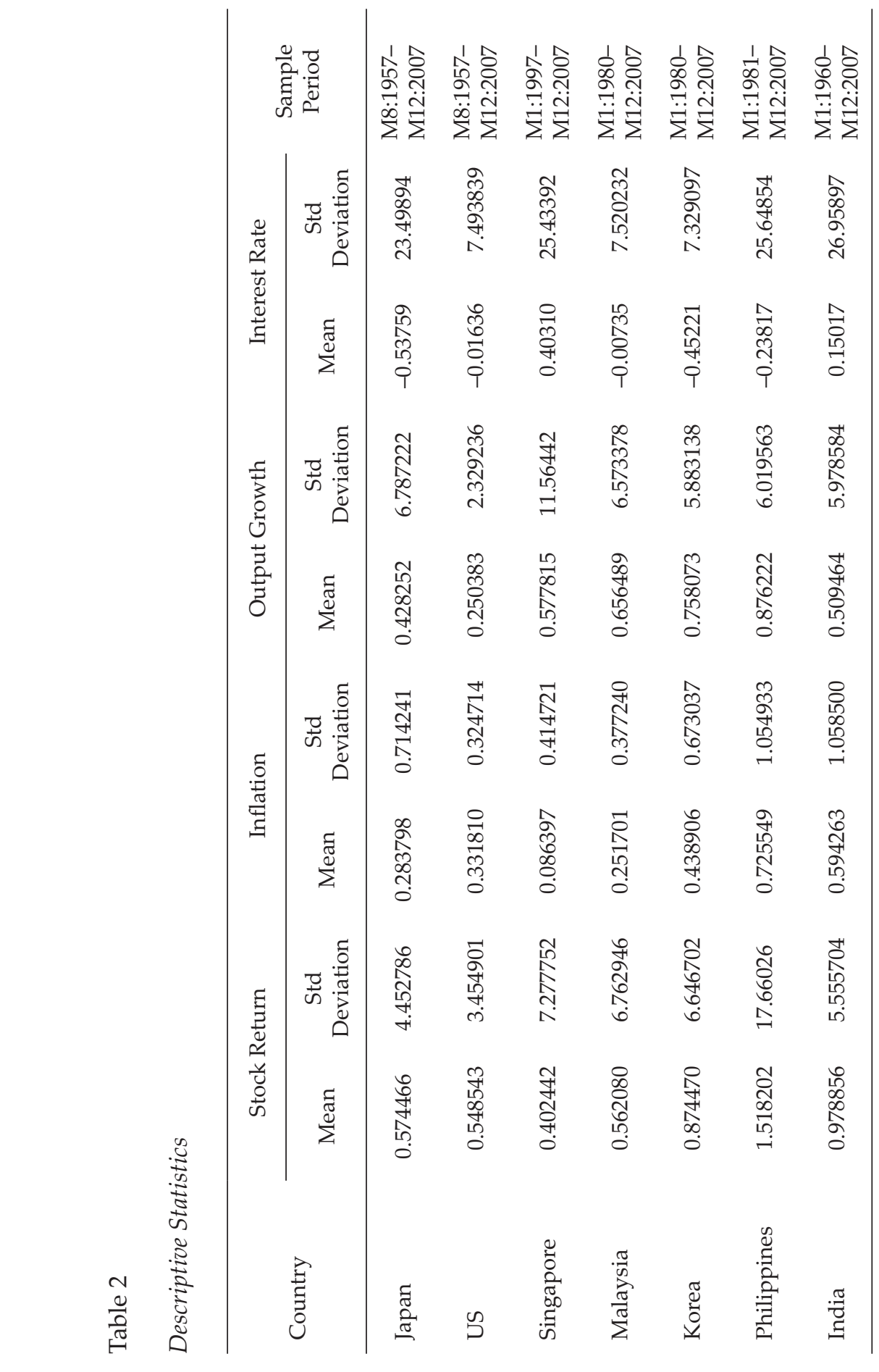

IJMS 17 (Special Issue), 63-84(2010) 73 


\section{Table 3}

GARCH (1,1) Estimates for Stock Returns

\begin{tabular}{lllll}
\hline & \multicolumn{1}{c}{$\begin{array}{c}\text { Mean } \\
\text { Equation }\end{array}$} & \multicolumn{2}{c}{ Conditional Variance Equation } \\
\cline { 2 - 5 } Country & Constant & Constant & $\alpha$ & $\beta$ \\
\hline Japan & $0.875360^{*}$ & $1.213492^{*}$ & $0.286685^{*}$ & $0.683251^{*}$ \\
USA & $0.634455^{*}$ & $1.086189^{* * *}$ & $0.093248^{* *}$ & $0.811681^{*}$ \\
Malaysia & $1.099107^{*}$ & $2.267284^{* *}$ & $0.244410^{* *}$ & $0.716426^{*}$ \\
Singapore & $0.929438^{* *}$ & 0.459555 & $0.171899^{* *}$ & $0.831281^{*}$ \\
Korea & $0.846179^{* *}$ & $1.299712^{* * *}$ & $0.118007^{* * *}$ & $0.850580^{*}$ \\
Philippines & 0.522986 & 7.968690 & $0.043099^{* * *}$ & $0.938478^{*}$ \\
India & $0.391058^{* *}$ & 0.088762 & $0.093413^{*}$ & $0.910270^{*}$ \\
\hline
\end{tabular}

Note. Asterisks $(*, * * * *)$ denote statistical significance at the $1 \%, 5 \%$ and $10 \%$ levels respectively.

Table 4

EGARCH $(1,1)$ Estimates for Stock Returns

\begin{tabular}{|c|c|c|c|c|c|}
\hline \multirow{2}{*}{ Country } & \multirow{2}{*}{$\begin{array}{c}\begin{array}{c}\text { Mean } \\
\text { Equation }\end{array} \\
\text { Constant }\end{array}$} & \multicolumn{4}{|c|}{ Conditional Variance Equation } \\
\hline & & Constant & $\alpha$ & $\beta$ & $\gamma$ \\
\hline Japan & $0.685643^{*}$ & 0.000498 & $0.429140^{*}$ & $0.874808^{*}$ & $-0.107802^{* * *}$ \\
\hline USA & $0.558887^{*}$ & $0.249281^{* *}$ & $0.190709^{* *}$ & $0.829840^{*}$ & $-0.175852^{*}$ \\
\hline Malaysia & 0.626919 & 0.156752 & $0.399690^{*}$ & $0.862835^{*}$ & $-0.179450^{* *}$ \\
\hline Singapore & $0.751980^{* * *}$ & 0.016866 & $0.219286^{* *}$ & $0.947531^{*}$ & $-0.126465^{* * *}$ \\
\hline Korea & $0.903452^{* *}$ & -0.000827 & $0.217954^{* * *}$ & $0.952143^{*}$ & -0.020691 \\
\hline Philippines & 0.525772 & $5.471884^{*}$ & $0.873788^{*}$ & -0.116382 & $0.257125^{* *}$ \\
\hline India & $0.441083^{* *}$ & 0.017654 & 0.002617 & $0.993290^{*}$ & $0.068710^{*}$ \\
\hline
\end{tabular}

Note. Asterisks $\left(*{ }^{* *},{ }^{* * *}\right)$ denote statistical significance at the $1 \%, 5 \%$, and $10 \%$ levels respectively.

74 IJMS 17 (Special Issue), 63-84 (2010) 


\section{Table 5}

The Cumulative Impact of Output Growth and Inflation on Stock Returns and Volatility (3 Month Horizon)

\begin{tabular}{|c|c|c|c|c|c|}
\hline \multirow[t]{2}{*}{ Country } & \multicolumn{2}{|c|}{ Returns } & \multicolumn{2}{|c|}{ Volatility } & \multirow[t]{2}{*}{ Diagnostic Tests } \\
\hline & $\sum_{i=1}^{3}$ Output & $\sum_{i=1}^{3}$ Inflation & $\sum_{i=1}^{3}$ Output & $\sum_{i=1}^{3}$ Inflation & \\
\hline Japan & $0.136771^{* * *}$ & -0.151951 & $-0.050500^{* *}$ & -0.045010 & $\begin{array}{l}Q=13.061 \\
Q^{2}=6.5791 \\
J B=40.86761^{*} \\
\text { ARCH }=0.015038\end{array}$ \\
\hline USA & $-0.256549^{* *}$ & $-2.087616^{*}$ & 0.033037 & $0.339693^{*}$ & $\begin{array}{l}Q=11.524 \\
Q^{2}=10.733 \\
J B=35.27363^{*} \\
\text { ARCH }=0.046730\end{array}$ \\
\hline Malaysia & -0.198354 & -0.109171 & -0.003022 & 0.030926 & $\begin{array}{l}Q=8.4543 \\
Q^{2}=8.7637 \\
J B=9.726066^{*} \\
A R C H=0.302208\end{array}$ \\
\hline
\end{tabular}

\begin{tabular}{|c|c|c|c|c|c|}
\hline Singapore & -0.103561 & -2.318395 & $-0.062054^{* * *}$ & 0.478050 & $\begin{array}{l}Q=13.847 \\
Q^{2}=14.597 \\
J B=3.155927 \\
A R C H=1.707335\end{array}$ \\
\hline
\end{tabular}

\begin{tabular}{|c|c|c|c|c|c|}
\hline Korea & -0.018636 & $-1.565998^{*}$ & $0.036697^{* * * *}$ & $0.091288^{*}$ & $\begin{array}{l}Q=4.9418 \\
Q^{2}=6.9164 \\
J B=0.140441 \\
A R C H=0.049390\end{array}$ \\
\hline
\end{tabular}

\begin{tabular}{|c|c|c|c|c|c|}
\hline Philippines & -0.057436 & $-0.411307^{*}$ & $0.230536^{*}$ & $-1.333707^{*}$ & $\begin{array}{l}Q=14.870 \\
Q^{2}=3.9086 \\
J B=253.4596^{*} \\
A R C H=0.037232\end{array}$ \\
\hline India & 0.091173 & -0.184002 & $0.017038^{* *}$ & $0.034790^{*}$ & $\begin{array}{l}Q=12.031 \\
Q^{2}=4.8228 \\
J B=1.876478 \\
A R C H=0.105341\end{array}$ \\
\hline
\end{tabular}

Notes. F-statistics (Using Wald-Coefficient Restriction) are for the statistical significance of the sum of three coefficients. Q-test is the test for serial correlation with lag $12, \mathrm{Q}^{2}$-test is the test for dependency in squared residuals at lag 12 , and $\mathrm{ARCH}$ is the F-statistics for ARCH LM Test with lag 1 . Asterisks $\left({ }^{*},{ }^{* *},{ }^{* *}\right)$ denote statistical significance at the $1 \%, 5 \%$, and $10 \%$ levels respectively. 


\section{Predictive Power of Output and Inflation}

To analyse the predictive power of output growth and inflation on monthly stock returns and volatility, both output growth and inflation are set to be the exogenous variables in both the mean and conditional variance simultaneously. The impact of changes in output growth and inflation on stock returns over a three-month horizon are reported in Table $5^{1}$. F-statistics are used to test the significance of the sum of the three coefficients for output and inflation on stock returns and volatility separately over a three-month period.

Results from Table 5 reveal that there is significant predictive power of output growth on monthly stock returns for both Japan and US. For instance, over a three-month period, a 1\% increase in output growth rate is associated with a cumulative effect of $0.136 \%$ rise and $0.256 \%$ fall in monthly stock return in Japan and US respectively. There is a positive relationship between output growth rate and stock return in Japan, but negative relation in US. Positive output growth rate can boost up investors confidence in the market. As compared to Asia $\mathrm{EM}$, there is no significant output predictive power on stock returns. The negative relation between inflation and stock return is consistent with Gregoriou, Hunter, and $\mathrm{Wu}$ (2009), where the transmission mechanism for real money into inflation is through consumption growth. In the long run, the monetary expansion on inflation cancels in response to similar increases in real stock returns. That is to say, consumptions react positively to stock returns, but these responses are reduced by the impact of inflation. From another perspective, negative relation between output growth and stock return could be justified in this way. Higher level of economic activity is considered temporary and is expected to follow trend reversion (a fall in the future), and hence causing current saving reduces stock returns (Tsouma, 2008).

The impact of inflation on stock returns being significant, this only occurs for US $(-2.09 \%)$, Korea $(-1.57 \%)$ and Philippines $(-0.41 \%)$. There is significant negative predictive power of inflation on stock returns, which implies that a $1 \%$ increase in inflation in US, reduces the stock returns by $2.09 \%$ over a three-month period. This result is also consistent with Ely and Robinson (1991), Kaul (1987), Solnik (1983), and Mundell (1963), who found negative relation between inflation and stock return. To justify the negative relation between inflation and stock return, Pigou real wealth effect showed that the real rate of interest is negatively related to expected inflation. Progressive taxes effect might explain the negative impact of inflation on stock returns. 
Current returns depend on future cash flows. If future tax liabilities increase due to the higher expectation of future inflation, it would reduce future cash flows and result in lower stock return.

For stock return volatility, generally the results showed that most countries show significant impact of output movements on stock return volatility, in which Asia EM depict stronger evidence. Philippines $(0.23 \%)$, Korea $(0.04 \%)$, and India $(0.02 \%)$ show significant positive impact of output growth on stock returns volatility, while there is significant negative impact for Japan $(-0.05 \%)$ and Singapore $(-0.06 \%)$. The latter countries exhibit higher volatility (Table 2 ) as compared to the former. This finding indicated that MM with relatively higher output volatility are associated with higher conditional volatility of stock returns and vice versa. The result is mixed for EM.

The effect of inflation on the conditional stock market volatility is significant for US $(0.34 \%)$, Korea $(0.09 \%)$, Philippines $(-1.33 \%)$, and India $(0.03 \%)$. This result indicated that the evidence of inflation volatility on stock return volatility is quite strong particularly for Asia EM. Low inflation rate countries tend to have more unreceptive effect on volatility than higher inflation rate countries. High inflation rate countries like Philippines are adversely affected stock market volatility.

The reported diagnostic tests indicated no evidence of significant autocorrelation and no evidence of dependency in squared residuals for all these countries.

\section{Inflation-Output Growth-Interest Rate-Stock Return (IOIS) Model}

By including interest rate changes, it improves the predictive power of output growth on stock returns. In terms of the impact of output growth on stock returns, there is improvement in IOIS model (Table 6) as compared to the previous model (Table 5). There is no autocorrelation pattern in the data series for both IOIS model and the previous model. This is confirmed by $\mathrm{Q}$ statistics, $\mathrm{Q}^{2}$ statistics, and $\mathrm{ARCH}$ tests from testing the null of no autocorrelation. Four countries show significant evidence where Japan $(0.14 \%)$ and Philippines $(0.37 \%)$ show positive relation between output growth on stock returns, and US and Malaysia (-0.21\%) show negative impact. Positive output growth will cause explicit earning growth and result in higher expected future dividends and ultimately increase the stock returns. Meanwhile, according to Ang (2008), economic booms encourage the adoption of a riskier behaviour and this will 
encourage speculative economic activities which can create overleveraged situations. The instability of stock speculation regarding over-leveraged situations can have severe negative consequences for an economy due to psychological factors.

In terms of the impact of inflation on stock returns, results revealed that there is no significant change in the IOIS Model as compared to the previous model. US, Korea, and Philippines have significant negative relation between inflation and stock returns. If the government is unable to obtain sufficient revenue to finance its sizeable expenditures, which would probably happen during economic crisis and stock return usually drop, the expected inflation would rise if the deficits are monetised, and result in negative relationship between inflation and stock returns. Out of seven countries, only Singapore and Philippines show significant negative relationship between interest rate changes and stock returns. The increase in interest rates for mere reasons of arbitrage means higher financing cost for investment in production and stock investment. Higher investment cost will cause the future earning to fall due to the plunge in future production, causing a reduction in future cash flows and hence leading to a reduction in stock returns. Besides that, higher interest rates will lead to higher cost to finance stock investment, hence reduce the willingness of investors in stock investment and cause the fall in stock price.

The evidence of output growth on stock return volatility in IOIS Model is relatively strong with five out of seven countries showing significant results, where US $(0.06 \%)$, Korea $(0.04 \%)$ and Philippines $(0.22 \%)$ show positive relation between output growth on stock return volatility, and Japan $(-0.04 \%)$ and Singapore $(-0.09 \%)$ show negative relations. Meanwhile, the predictive power of inflation on stock return volatility in IOIS Model is akin with the result in Table 5. It is noteworthy that Philippines exhibits a negative relationship between inflation and stock return volatility, while US, Korea, and India evidently show positive relation. The amplitude of inflation on stock return volatility is substantial for Philippines. Therefore, policy makers should take precautionary steps to manage inflation due to its large impact on stock return volatility. On the other hand, the predictive power of interest rate changes on stock return volatility is moderate. US and Malaysia show negative relation. Such negative relation suggests that the removal of interest rate controls may promote financial development. Only Philippines shows positive relation between interest rate and stock volatility, suggesting that financial liberalisation appears to have positive effect on asset return progress. However, the amplitude of the impact is relatively small. 


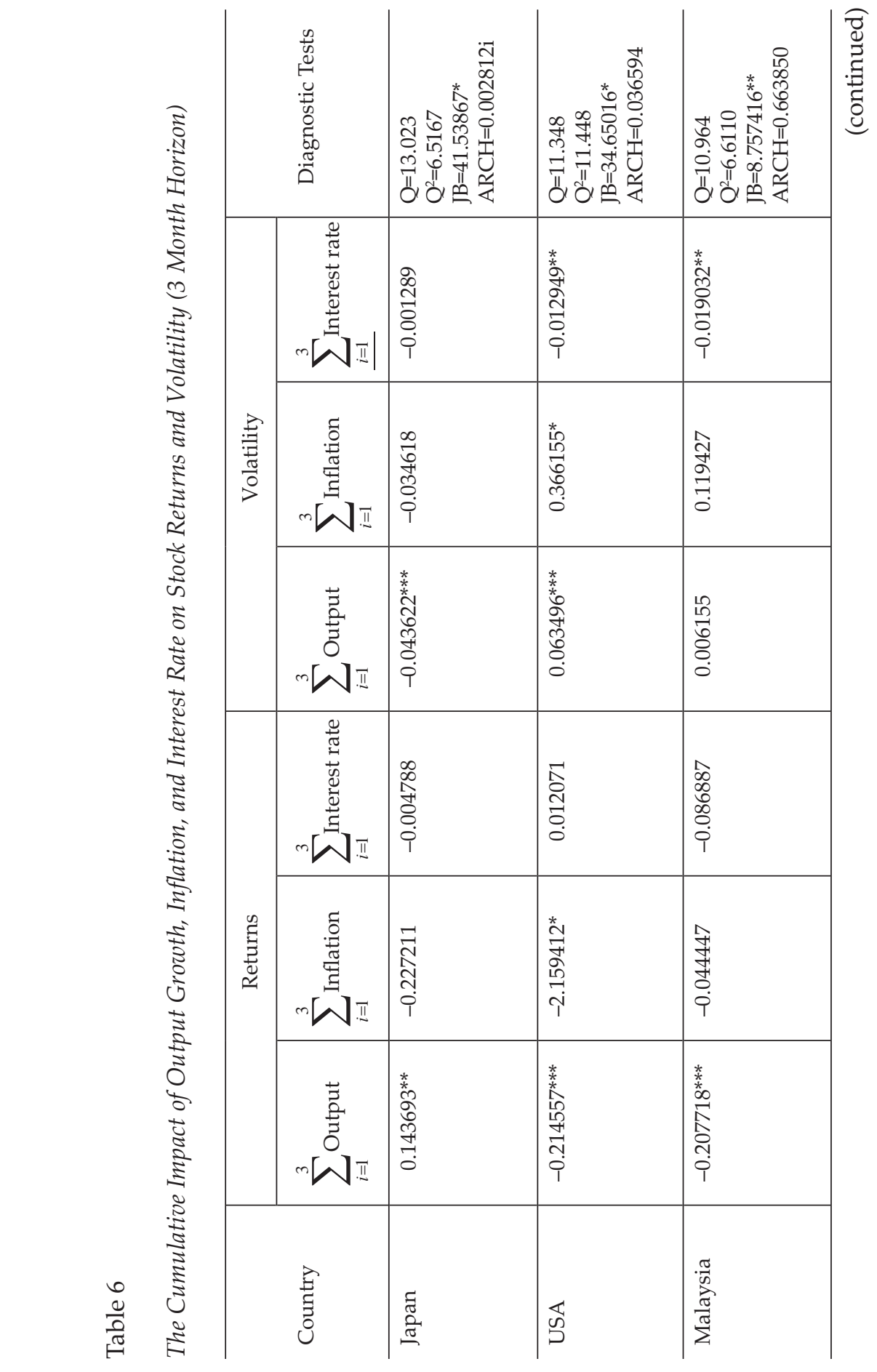

IJMS 17 (Special Issue), 63-84(2010) 79 


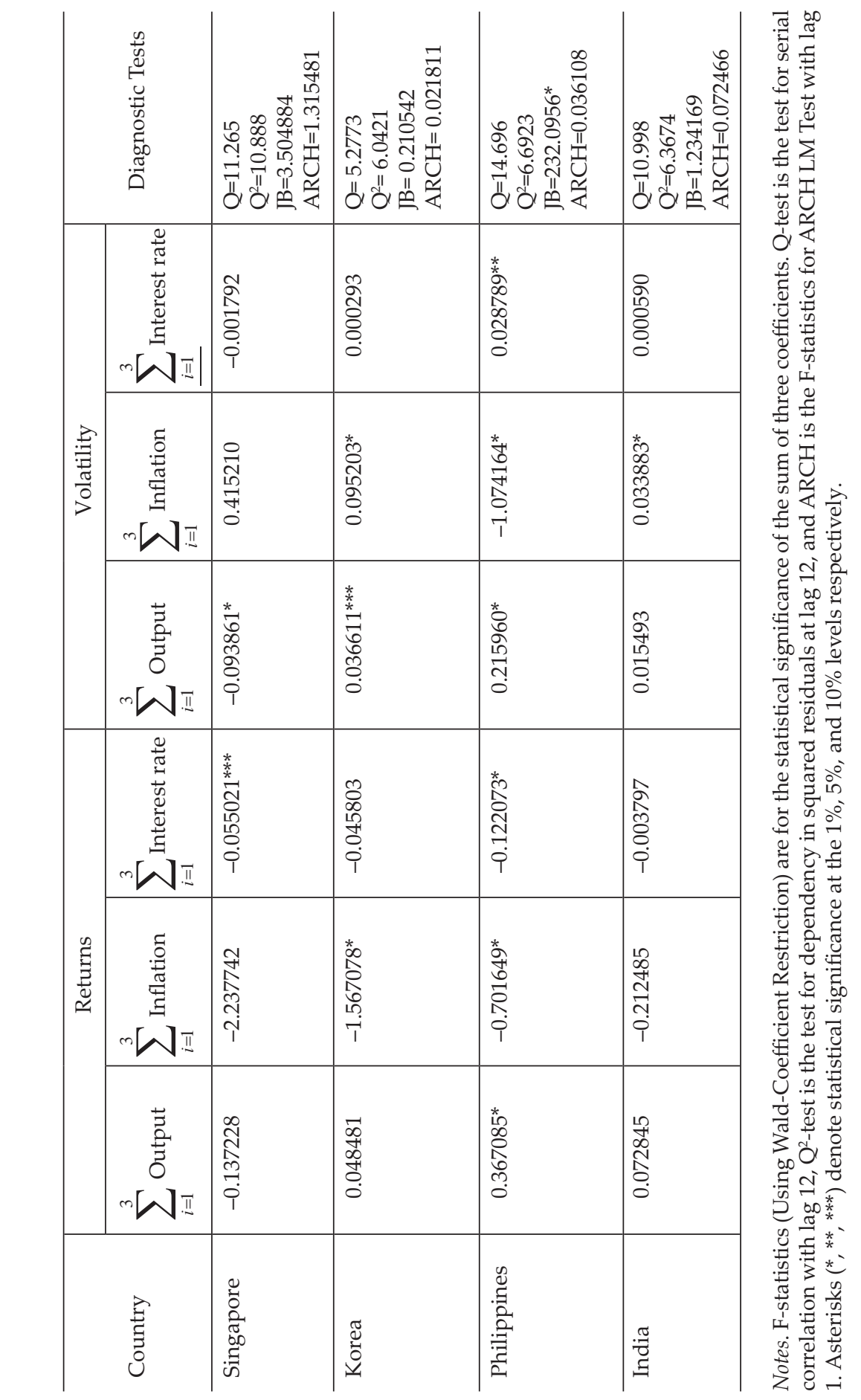

80 IJMS 17 (Special Issue), 63-84 (2010) 


\section{Conclusion}

Using GARCH and EGARCH models, this paper examined the predictive power of output growth and inflation on stock return and its volatility. Results revealed strong evidence of output growth and inflation on stock return volatility, where more evidences where shown in Asian financial crisis affected countries as compared to US and Japan. The evidence of output growth on stock return is extremely different between MM and Asia crisis EM, as both US and Japan show significant evidence that output growth acts as an important determinant to determine stock returns, but none of the Asia EM under study revealed significant results. It is noteworthy that the evidence of predictive power of inflation on stock return does not support the Adaptive Fisher effect in stock return. This could be justified using Pigou real wealth effect. Progressive tax effect might explain the negative impact of inflation on stock returns. Generally, the negative impact of inflation to predict stock return is significant in US, Korea, and Philippines. Results revealed that four out of seven countries show significant evidence of the predictive power of inflation on stock return volatility. High inflation influences stock return volatility in Philippines. This result provides important insight for policy makers to control inflation to reduce the stock return volatility since higher volatility means higher risk for investors.

The result from IOIS Model showed that the inclusion of interest rate changes improves the prediction power of the output growth on the stock return. Japan and Philippines show positive relation in which positive output growth will cause positive earning growth and bring better expected future dividends and ultimately cause the stock return to increase. Even with the inclusion of interest rate changes, results do not support the Fisher Effect. The negative relationship between inflation and stock return might be caused by the deficit fiscal policy carried out by the government. If the government fails to obtain sufficient revenue to finance its large expenditures, the expected inflation will increase and bring negative effect on stock return. The result also proves that interest rate changes do have some significant influences on stock return volatility in US, Malaysia, and Philippines although the direction of impact is ambiguous.

For future study, there is much room for improvement to examine other factors that influence the stock return and its volatility such as money supply growth rate, saving rate, income per capita, political 
stability, stock market regulation, and etc. One may extend the sample period across the sample countries to improve the predictive power of the model.

\section{Endnote}

1. Only the results with respect to output and inflation are reported here. Past stock returns and the estimates of the GARCH coefficients including the coefficient for dummies are not reported here.

\section{References}

Aggarwal, R., Inclan, C., \& Leal, R. (1999). Volatility in emerging stock markets. Journal of Financial and Quantitative Analysis, 34(1), 33-55.

Ang, J. B. (2008). What are the mechanisms linking financial development and economic growth in Malaysia. Economic Modelling, 25, 38-53.

Balvers, R. J., Cosimano, T. F., \& McDonald, B. (1990). Predicting stock returns in an efficient market. Journal of Finance, 45(4), 11091128.

Bekaert, G., \& Harvey, C. R. (1997). Emerging market volatility. Journal of Financial Economics, 43, $29-77$.

Bekaert, G., \& Harvey, C. R. (2004). A chronology of important financial, economic and political events in emerging markets. Retrieved from http://www.duke.edu/

Binswanger, M. (2000). Stock market booms and real economic activity: Is this time different? International Review of Economics and Finance, 9, 387-415.

Bollerslev, T. (1986). Generalised autoregresive conditional heteroskedasticity. Journal of Econometric, 31, 307-327.

Bollerslev, T., \& Wooldridge, J. M. (1992). Quasi-maximum likelihood estimation and inference in dynamic models with time varying covariances. Econometric Reviews, 11, 143-172.

Braun, P. A., Nelson, D. B., \& Sunier, A. M. (1995). Good news, bad news, volatility, and betas. Journal of Finance, 1(5), 575-603.

Campbell, J. Y., \& Hentschel, L. (1992). No news is good news: An asymmetric model of changing volatility in stock returns. Journal of Financial Economics, 31, 281-318.

Davis, N., \& Kutan, A. M. (2003). Inflation and output as predictors of stock returns and volatility: International evidence. Applied Financial Economics, 13, 693-700.

82 IJMS 17 (Special Issue), 63-84 (2010) 
Domian, D. L., Gilster, J. E., \& Louton, D. A. (1996). Expected inflation, interest rates, and stock returns. The Financial Review, 31(4), 809-830.

Ely, D. P., \& Robinson, K. J. (1991, June). Stock returns and inflation: Further tests of the role of the Central Bank. Federal Reserve Bank of Dallas Working Paper.

Fama, E. F., \& Schwert, G. W. (1977). Asset returns and inflation. Journal of Financial Economics, 5, 115-146.

Fisher, I. (1930). The theory of interest. New York, NY: Macmillan.

Geske, R., \& Roll, R. (1983). The monetary of fiscal linkage between stock returns and inflation. Journal of Finance, 38, 1-33.

Gregoriou, A., Hunter, J., \& Wu, F. (2009). An empirical investigation of the relationship between the real economy and stock returns for the United States. Journal of Policy Modeling, 31, 133-143.

Hamilton, J. D., \& Lin, G. (1996). Stock market volatility and the business cycle. Journal of Applied Econometrics, 11, 573-593.

Hassapis, C., \& Kalyvitis, S. (2002). Investigating the links between growth and real stock price changes with empirical evidence from the G-7 economies. The Quarterly Review of Economics and Finance, 42(3), 543-575.

Kaul, G. (1987). Stock returns and inflation: The role of the monetary sector. Journal of Financial Economics, 18, 253-276.

Lee, B. S. (1992). Causal relations among stock returns, interest rates, real activity, and inflation. The Journal of Finance, 47(4), 15911603.

Mascaro, A., \& Meltzer, A. H. (1983). Long and short term interest in a risky world, Journal of Monetary Economics, 12, 485-518.

Mauro, P. (2000). Stock returns and output growth in emerging and adcanced economies. IMF Working Paper no. WP/00/89.

McQueen, G., \& Roley, V. V. (1993). Stock prices, news and business conditions. Review of Financial Studies, 6, 683-707.

Mundell, R. (1963). Inflation and real interest. Journal of Political Economy, 71, 280-283.

Nelson, D. B. (1991). Conditional heteroskedasticity in asset returns: A new approach. Econometrica, 59, 347-370.

Officer, R. R. (1973). The variability of the market factor of New York Stock Exchange. Journal of Business, 46, 434-453.

Peiro, A. (1996). Stock prices, production and interest rates: Comparison of three European countries with USA. Empirical Economics, 21, 221-234.

Santomero, A. M. (1973). A note on the interest rates and prices in general equilibrium. Journal of Finance, 38, 997-1000.

Schwert, W.G. (1989a). Why does stock market volatility change over time? Journal of Finance, 54(5), 1115-53. 
Schwert, W. G. (1989b). Business cycles, financial crisis and stock volality, Carnegie-Rochester Conference Series on Public, 31, 83125.

Solnik, B. (1983). The relationship between stock prices and inflationary expectations: The international evidence. Journal of Finance, 38, 35-48.

Titman, S., \& Warga, A. (1989). Stock returns as predictors of interest rates and inflation. Journal of Financial and Quantitative Analysis, 24(1), 47-58.

Tsouma, E. (2008). Stock returns and economic activity in mature and emerging markets. The Quarterly Review of Economics and Finance, 49 (2) 668-685.

84 IJMS 17 (Special Issue), 63-84 (2010) 